\title{
PENERAPAN METODE FUZZY PADA SISTEM MONITORING PERKEMBANGAN TANAMAN HIDROPONIK
}

\author{
Muhammad Luthfi Andhikaputra, Ahmad Faisol, Karina Auliasari \\ Program Studi Teknik Informatika S1, Fakultas Teknologi Industri \\ Institut Teknologi Nasional Malang, Jalan Raya Karanglo km 2 Malang, Indonesia \\ 1718122@scholar.itn.ac.id
}

\begin{abstract}
ABSTRAK
Hidup di perkotaan, terutama di kota-kota besar, identik dengan lingkungan yang sesak dan jauh dari kesan tanaman hijau. Jangankan bertanam komoditas pangan, menghasilkan sayuran berumur pendek yang bisa dikonsumsi sendiri saja rasanya mustahil. Dengan adanya teknik menanam tanpa tanah dan sangat mungkin diterapkan di dalam ruangan, sistem hidroponik adalah solusi pertanian yang sangat potensial untuk dikembangkan di wilayah perkotaan. Dengan adanya dukungan sistem monitoring dapat mempermudah proses bercocok tanam pada hidroponik, dimana kita tidak perlu lagi mengecek secara manual untuk mengetahui kondisi tanaman hidroponik. Dengan sistem monitoring ini juga mempunyai sistem otomasi yang berfungsi untuk mengatur kondisi yang dibutuhkan oleh tanaman hidroponik. Pada sistem otomasi tanaman hidroponik menggunakan sensor DHT22 digunakan untuk mendeteksi suhu dan kelembaban, sensor TDS digunakan untuk mendeteksi nutrisi, dan sensor $\mathrm{pH}$ untuk mendeteksi kadar $\mathrm{pH}$ pada bak penampung hidroponik. Dengan latar belakang permasalahan di atas peneliti mengajukan penelitian untuk membuat sebuah sistem yang terintegrasi dengan internet sehingga dapat terpantau oleh pemilik tanaman hanya dengan menggunakan smartphone. Dan membuat sebuah sistem otomasi dengan menerapkan metode Fuzzy sebagai pengambilan keputusan untuk menentukan kadar nutrisi, kelembaban dan ph yang dibutuhkan oleh tanaman hidroponik. Dari hasil pengujian menunjukkan bahwa alat monitoring dengan menerapkan metode fuzzy dapat berjalan dengan baik. Dimana pompa akan menyala dengan lama waktu yang telah ditentukan dengan menggunakan logika fuzzy (satuan millisecond) ketika kondisi ph memasuki kondisi keanggotaan fuzzy asam, dan basa. Pompa untuk suhu dan kelembaban juga akan menyala ketika memasuki nilai keanggotaan dalam kondisi kering dan panas dan akan mati jika memasuki kondisi lembab dan dingin. Dan pompa nutrisi akan menyala ketika memasuki kondisi kurang dengan lama waktu yang telah ditentukan dengan menggunakan logika fuzzy.
\end{abstract}

Kata Kunci : logika fuzzy, ph, nutisi, kelembaban.

\section{PENDAHULUAN}

Hidup di perkotaan, terutama di kota-kota besar, identik dengan lingkungan yang sesak dan jauh dari kesan tanaman hijau. Jangankan bertanam komoditas pangan, menghasilkan sayuran berumur pendek yang bisa dikonsumsi sendiri saja rasanya mustahil. Dengan adanya teknik menanam tanpa tanah dan sangat mungkin diterapkan di dalam ruangan, sistem hidroponik adalah solusi pertanian yang sangat potensial untuk dikembangkan di wilayah perkotaan. Selain dekoratif pemanfaatan hasil bertanam hidroponik dapat langsung dirasakan oleh pemilik dan lingkungan sekitar, seperti menanam sayuran yang dapat langsung dikonsumsi oleh pemilik.

Dengan kemajuan teknologi komunikasi ini berdampak pada banyaknya media komunikasi yang dapat digunakan dalam menyebarluaskan informasi mengenai pertanian dan sebagainya. Perkembangan dan kemajuan teknologi juga terdapat dalam bidang IoT (Internet of Things) telah banyak dimanfaatkan dalam berbagai bidang guna membantu mempermudah pekerjaan manusia. Dengan menerapkan sistem kendali secara otomatis pada cocok tanam dengan menggunakan teknologi IoT dapat menjadi solusi memudahkan dalam proses cocok tanam dan menghasilkan sayuran yang lebih terjaga kualitasnya.

Dengan latar belakang permasalahan di atas peneliti mengajukan penelitian untuk membuat sebuah sistem yang terintegrasi dengan internet sehingga dapat terpantau oleh pemilik tanaman hanya dengan menggunakan smartphone. Dan membuat sebuah sistem otomasi dengan menerapkan metode Fuzzy sebagai pengambilan keputusan untuk

menentukan kadar nutrisi, kelembaban dan ph yang dibutuhkan oleh tanaman hidroponik.

\section{TINJAUAN PUSTAKA}

\subsection{Penelitian Terdahulu}

Afif Algifari, pada tahun 2014 pada penelitian dengan judul "PERANCANGAN KIPAS ANGIN PENGATUR SUHU DAN KELEMBAPAN RUANGAN DENGAN METODE FUZZY SUGENO BERBASIS ARDUINO”. Tujuan penelitian ini yaitu untuk membuat sistem pengatur suhu dan kelmebaban ruangan dengan menggunakan metode fuzzy sugeno pada sistem Arduino, dan mengamati respon sistem yang dihasilkan teknik kendali yang diterapkan adalah fuzzy sugeno[1]

Kridho Cokro Bagaskoro, di tahun 2019 membuat penelitian dengan judul "PENGUNAAN 
ARDUINO UNO UNTUK PENGUKURAN SUHU, PH DAN DO AIR KOLAM IKAN BAWAL MENGGUNAKAN LOGIKA FUZZY'. Tujuan Penelitian ini adalah membuat sebuah alat untuk mengukur takaran standar air pada kolam ikan bawal tersebut dan juga merancang sebuah sistem yang memberikan keakuratan kebenaranya mengunakan logika fuzzy. [2]

Anizar Indriani, di tahun 2019 pada penelitian membuat penelitian dengan judul "KONTROL KUALITAS KADAR AIR LAUT MENGGUNAKAN FUZZY LOGIC UNTUK HABITAT IKAN KERAPU”. Tujuan penelitian ini adalah membuat alat untuk pengendalian kualitas air laut untuk menjaga kualitas kolam ikan kerapu yang terdiri dari temperatur, salinitas, keasaman $(\mathrm{pH})$ dan kekeruhan air laut. [3]

Siti Khodijah pada penelitiannya yang berujudul "PERANCANGAN DAN IMPLEMENTASI ALAT UKUR UNTUK PENENTUAN KUALITAS AIR BERBASIS LOGIKA FUZZY METODE SUGENO" Tujuan penelitian ini adalah membuat sebuah alat untuk mengetahui kualitas air sungai. Pada alat terpasang dua buah sensor, yaitu sensor $\mathrm{pH}$ dan sensor kekeruhan yang diproses dengan menggunakan logika fuzzy metode sugeno untuk mendapatkan status aman atau tidaknya air sungai tersebut untuk digunakan pada manusia. [4]

Renggy Nikiuluw pada penelitiannya yang berujudul "KENDALI SUHU MENGGUNAKAN FUZZY LOGIC UNTUK SISTEM PASTEURISASI SUSU". Tujuan penelitian ini adalah membuat rancang bangun kendali suhu pada sistem pasteurisasi menggunakan metode fuzzy logic sugeno. Pada fuzzy logic ini memiliki input berupa nilai suhu dan perubahan suhu pada susu secara real time selama 30 menit. Output dari fuzzy logic yang digunakan memiliki 9 rule yang telah ditetapkan oleh penulis dengan output berupa actuator servo yang berfungsi sebagai pengatur besar hingga kecilnya api kompor. [5]

\subsection{IoT (Internet of Things)}

IoT (Internet of Things) adalah sebuah konsep/skenario dimana suatu objek yang memiliki kemampuan untuk mentransfer data melalui jaringan tanpa memerlukan interaksi manusia ke manusia atau manusia ke komputer. IoT adalah sebuah jaringan yang menghubungkan suatu alat sehingga dapat berkomunikasi tanpa bantuan manusia.

\subsection{Logika Fuzzy}

Pendekatan fuzzy logic diimplementasikan dalam tiga tahapan, yaitu: fuzzifikasi, evaluasi rule (inferensi), dan defuzzifikasi [13].

\section{a. Fuzzyfikasi}

Merupakan fase pertama dari perhitungan fuzzy, yaitu mengubah masukan-masukan yang nilai kebenarannya bersifat pasti kedalam bentuk fuzzy input yang berupa tingat keanggotaan/ tingkat kebenaran. Dengan demikian, tahap ini mengambil nilai-nilai crisp dan menentukan derajat dimana nilai-nilai tersebut menjadi anggota dari setiap himpunan fuzzy yang sesuai.

\section{b. Inferensi}

Inferensi adalah melakukan penalaran menggunakan fuzzy input dan fuzzy rules yang telah ditentukan sehingga menghasilkan fuzzy output. Secara sintaks, suatu fuzzy rule (aturan fuzzy) dituliskan sebagai berikut: IF antecendent THEN consequent

\section{c. Defuzzifikasi}

Defuzzifikasi adalah mengubah fuzzyoutput menjadi nilai tegasberdasarkan fungsi keanggotaan yang telah ditentukan. Defuzzifikasi merupakan metode yang penting dalam pemodelan system fuzzy.

\subsection{Arduino Uno}

Arduino Uno adalah papan mikrokontroler open source berbasis mikrokontroler Microchip ATmega328P dan dikembangkan oleh Arduino.cc. Papan ini dilengkapi dengan set pin input / output digital dan analog yang dapat dihubungkan ke berbagai papan ekspansi dan sirkuit lainnya.

\subsection{NodeMCU ESP8266}

NodeMCU bisa dianalogikan sebagai board arduino-nya ESP8266. Arduino NodeMCU adalah sebuah platform IoT yang bersifat opensource. Terdiri dari perangkat keras berupa System on Chip ESP8266 dari ESP8266 buatan Espressif System, juga firmware yang digunakan, yang menggunakan bahasa pemrograman scripting Lua. Istilah NodeMCU secara default sebenarnya mengacu pada firmware yang digunakan daripada perangkat keras development kit.

\subsection{Sensor $\mathrm{pH}$}

Sensor PH adalah jenis sensor kimia yang dimana output yang akan ditampilkan adalah hasil dari reaksi kimia yang terdeteksi lalu dirubah kedalam besaran tegangan listrik. Terdapat 2 jenis elektroda pada sensor $\mathrm{pH}$, yaitu elektroda kaca dan elektroda referensi. Elektroda kaca memiliki fungsi mengukur jumlah ion yang ada pada larutan dan elektroda referensi digunakan untuk merubah jumlah ion yang terdeteksi oleh elektroda kaca menjadi tegangan analog.

\subsection{Sensor TDS}

Merupakan sensor kompatibel Arduino yang digunakan untuk mengukur kadar TDS (Total Dissolve Solid) pada air. TDS sendiri merupakan kadar konsentrasi objek solid yang terlarut dalam air. Semakin tinggi nilai TDS nya maka semakin keruh airnya, begitupun sebaliknya. Semakin rendah nilai TDS nya maka semakin jernih pula air tersebut.

\subsection{Sensor DHT}

Sensor DHT merupakan paket sensor yang berfungsi untuk mengukur suhu dan kelembaban udara 
sekaligus yang dialamnya terdapat thermistor tipe NTC (Negative Temperature Coefficient) untuk mengukur suhu, sebuah sensor kelembapan dengan karkteristik resistif terhadap perubahan kadar air di udara serta terdapat chip yang di dalamnya melakukan beberapa konversi analog ke digital dan mengeluarkan output dengan format single-wire bi-directional (kabel tunggal dua arah).

\subsection{Relay}

Relay adalah Saklar (Switch) yang dioperasikan secara listrik dan merupakan komponen Electromechanical (Elektromekanikal) yang terdiri dari 2 bagian utama yakni Elektromagnet (Coil) dan Mekanikal (seperangkat Kontak Saklar/Switch). Relay menggunakan Prinsip Elektromagnetik untuk menggerakkan Kontak Saklar sehingga dengan arus listrik yang kecil (low power) dapat menghantarkan listrik yang bertegangan lebih tinggi.

\subsection{Pompa Air DC 12v}

Pompa air adalah alat untuk menggerakan air dari tempat bertekanan rendah ke tempat bertekanan yang lebih tinggi. Proses tersebut dilakukan setelah membuat suatu tekanan yang rendah pada sisi masuk air dan tekanan yang tinggi pada sisi keluar air dari pompa.

\section{METODE PENELITIAN}

\subsection{Kebutuhan Nonfungsional}

Adapun beberapa kebutuhan fungsional dalam rancang bangun sistem ini antara lain:

1. Aplikasi yang dikembangkan harus bisa diakses selama 24 jam.

2. Aplikasi yang dikembangkan harus dapat menampilkan data dari sensor yang ada di sistem hidroponik.

3. Aplikasi yang dikembangkan hanya bisa berjalan jika device telah terkoneksi ke internet.

4. Aplikasi yang dikembangkan dapat berjalan pada Android minimal versi 7.0.

\subsection{Kebutuhan Fungsional}

Adapun beberapa kebutuhan fungsional dalam rancang bangun sistem monitoring hidroponik antara lain:

Tabel 1. Kebutuhan Fungsional

\begin{tabular}{|c|c|l|}
\hline No. & $\begin{array}{c}\text { Halaman } \\
\text { Menu }\end{array}$ & \multicolumn{1}{c|}{ Fungsional } \\
\hline 1 & Data Sensor & Menampilkan menu data sensor \\
\hline 2 & Hidroponik & $\begin{array}{l}\text { Menampilkan penjelasan singkat } \\
\text { mengenai sistem tanam hidroponik }\end{array}$ \\
\hline 3 & Temperature & $\begin{array}{l}\text { Menampilkan data temperature dari } \\
\text { sensor DHT22 }\end{array}$ \\
\hline 4 & Humidity & $\begin{array}{l}\text { Menampilkan data kelembaban dari } \\
\text { sensor DHT22 }\end{array}$ \\
\hline 5 & $\mathrm{Ppm}$ & $\begin{array}{l}\text { Menampilkan data nutrisi dari } \\
\text { sensor TDS }\end{array}$ \\
\hline 6 & $\mathrm{Ph}$ & $\begin{array}{l}\text { Menampilkan data pH dari sensor } \\
\text { pH }\end{array}$ \\
\hline
\end{tabular}

Pada table 1 dapat dilihat bahwa aplikasi monitoring ini memiliki 6 menu yang dapat diakses oleh pengguna, diantaranya adalah menu data sensor, menu hidroponik, menu temperature, menu humidity, menu ppm, menu ph. Menu data sensor berfungsi untuk menampilkan menu pilihan untuk melihat data dari sensor. Menu hidroponik berfungsi untuk menampilkan penjelasan singkat mengenai sistem cocok tanam hidroponik. Selanjutnya adalah menu temperature yang berfungsi untuk menampilkan data yang ditangkap oleh sensor DHT22. Menu selanjutnya adalah humidity yang berfungsi untuk menampilkan data kelembaban dari sensor DHT22. Menu ppm berfungsi untuk menampilkan data kadar nutrisi yang ditangkap oleh sensor TDS. Dan yang terakhir adalah menu ph, berfungsi untuk menampilkan data ph dari sensor ph.

\subsection{Diagram Blok Sistem Monitoring Perkembangan Tanaman Hidroponik}

Sistem monitoring pada tanaman hidroponik ini menggunakan mikrokontroler arduino uno r3 sebagai pengelola data. Data yang didapatkan dari sensor berupa data suhu, kelembaban, ppm, dan ph dikirim lalu diolah oleh arduino uno dengan menggunakan metode logika fuzzy. Kemudian data yang didapatkan akan dikirimkan menggunakan serial komunikasi ke nodeMCU ESP8266 untuk disimpan ke database dan dapat ditampilkan melalui android sehingga dapat dilihat oleh User. Blok diagram sistem monitoring dapat dilihat pada gambar 1 .

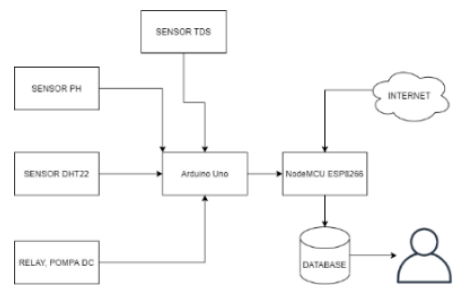

Gambar 1. Diagram blok sistem monitoring pada tanaman hidroponik

\subsection{Alokasi Pin}

Alokasi pin untuk sistem monitoring sensor dapat dilihat pada Tabel 2 .

Tabel 2. Alokasi pin sistem monitoring

\begin{tabular}{|c|c|c|c|c|}
\hline $\begin{array}{c}\text { Arduino } \\
\text { Uno }\end{array}$ & $\begin{array}{c}\text { nodeMCU } \\
\text { ESP8266 }\end{array}$ & $\begin{array}{c}\text { Sensor } \\
\text { dht22 }\end{array}$ & $\begin{array}{c}\text { Sensor } \\
\text { TDS }\end{array}$ & $\begin{array}{c}\text { Sensor } \\
\text { PH }\end{array}$ \\
\hline VCC & - & VCC & VCC & VCC \\
\hline GND & GND & GND & GND & GND \\
\hline Pin Rx & D7 & - & - & - \\
\hline Pin Tx & D6 & - & - & - \\
\hline Pin2 & - & Data & - & - \\
\hline Pin A1 & - & - & Data & - \\
\hline Pin A2 & - & - & - & Data \\
\hline
\end{tabular}

Pada tabel diatas ketiga sensor dan nodeMCU esp8266 memerlukan vcc dan gnd(ground), kemudian serial komunikasi nodeMCU esp8266 dihubungan pada pin 
6 dan 7. Sedangan sensor dht22 dihubungan pada pin 2, sensor tds pada pin A1, dan sensor ph pada pin A2.

\subsection{Desain Arsitektur Sistem}

Flowchart sistem ini menjelaskan proses berjalananya aplikasi seperti ditunjukkan pada Gambar 2.

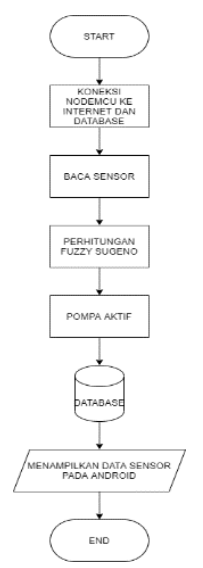

\section{Gambar 2. Flowchart Sistem}

\subsection{Struktur Menu Aplikasi}

Aplikasi monitoring pada sistem monitoring tanaman hidroponik menampilkan halaman utama sebagai monitoring alat, dan terdapat 2 menu yaitu data sensor dan hidroponik. Berikut stuktur menu pada aplikasi dapat dilihat pada gambar 3 .

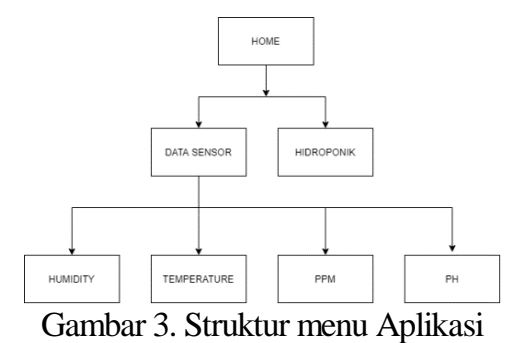

\section{HASIL DAN PEMBAHASAN}

\subsection{Bentuk Alat Monitoring Hidroponik}

Bentuk alat yang akan digunakan dalam sistem monitoring tanaman hidroponik dapat dilihat pada gambar 4 Pada gambar di bawah terdapat pipa yang digunakan untuk meletakkan tanaman pakcoy dengan sistem tanam hidroponik. Kemudian sistem otomasi untuk pengimplementasian dari 21 metode logika fuzzy terletak dibawah sistem tanam hidroponik. Dimana pada sistem terdapat 4 buah pompa untuk memompa larutan nutrisi A dan B, pH Up dan Down, dan juga nozzle untuk mengatur suhu dan kelembaban pada tanaman. Untuk mikrokontroler yang digunakan untuk menyalakan pompa terletak pada kotak yang ada di bawah pompa. Dan juga dapat dilihat bahwa dibagian bawah juga terdapat penampungan untuk larutan nutrisi, $\mathrm{pH}$ dan juga bak penampungan air yang digunakan untuk mengaliri sistem hidroponik. Dapat dilihat juga pada gambar 5 adalah bentuk sistem hidroponik yang akan digunakan pada penelitian ini. Pada sistem hidroponik terdapat 4 tingkat pipa yang disetiap pipa terdapat 8 lubang yang digunakan sebagai tempat untuk menanam tanaman. Setiap lubang memiliki jarak sebesar $20 \mathrm{~cm}$. Panjang dari setiap pipa adalah $190 \mathrm{~cm}$. Dapat dilihat juga terdapat sebuah bak tampungan dibagian bawah rangkaian sistem hidroponik berguna untuk menampung air nutrisi, yang akan dialirkan untuk tanaman hidroponik. Pada bagian dalam bak tampungan terdapat pompa, digunakan sebagai pemompa air nutrisi untuk tanaman hidroponik.

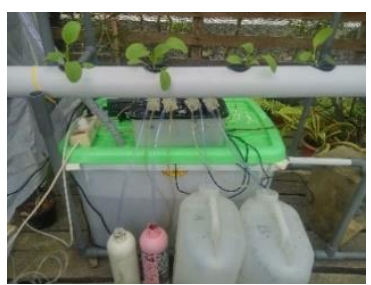

Gambar 4. Bentuk alat montoring hidroponik

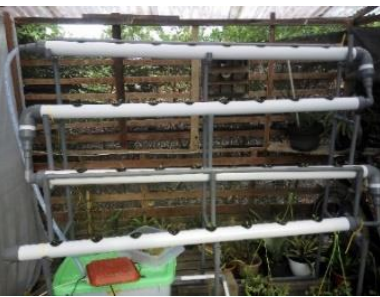

Gambar 5. Bentuk Sistem Hidroponik

\subsection{Tampilan Halaman Dashboard}

Halaman Home digunakan untuk monitoring data terakhir dan terbaru dari sensor pada sistem monitoring hidroponik. Tampilan halaman Utama bisa dilihat pada Gambar 5.

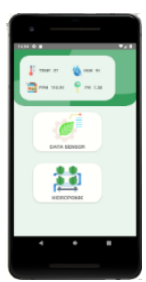

Gambar 6. Tampilan halaman utama

\subsection{Tampilan Halaman Menu Data Sensor}

Pada halaman data terdapat beberapa menu yang di setiap menu akan menampilkan data dari sensor yang dikirimkan melalui nodeMCU. Tampilan halaman data bisa dilihat pada gambar 6 .

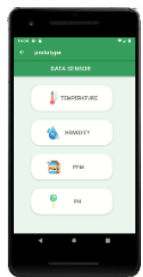

Gambar 7. Tampilan Halaman Menu Data Sensor 


\subsection{Tampilan Halaman Data Sensor}

Pada halaman data akan menampilkan data yang telah disimpan pada database dan ditampilkan pada tampilan menu data sensor, bisa dilihat pada gambar 7 .

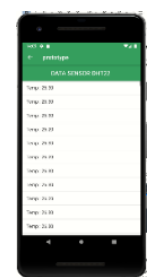

Gambar 8. Tampilan Halaman Data Sensor

\subsection{Tampilan Halaman Hidroponik}

Pada halaman hidroponik berisi tentang deskripsi mengenai cara bertanam menggunakan hidroponik bisa dilihat pada gambar 8 .

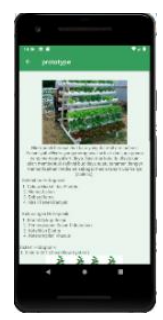

Gambar 9. Tampilan Halaman Hidroponik

\subsection{Himpunan Keanggotaan Fuzzy}

Untuk himpunan keanggotaan yang akan digunakan dalam sistem menggunakan perhitungan logika fuzzy adalah sebagai berikut.

a. Himpunan keanggotaan ph

Dimana himpunan keanggotaan untuk ph adalah asam pada range antara dibawah 5 sampai dengan 7 . Untuk keanggotaan netral adalah range antara 7 sampai dengan 9, dan keanggotaan basa adalah di atas 9.

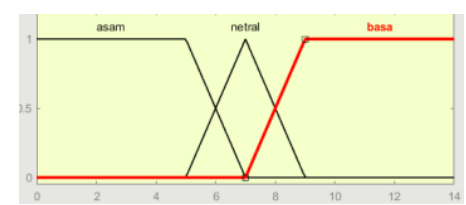

Gambar 10. Himpunan keanggotaan ph

Jika dimasukkan kedalam Rumusan fungsi keanggotaan adalah sebagai berikut :

\begin{tabular}{crcr}
\multicolumn{2}{c}{ Keanggotaan } & Asam : & \multicolumn{2}{c}{ Keanggotaan Basa : } \\
1, & $x \leq 5$ & 0, & $x \leq 7$ \\
$7-x$ & & $x-7$ & $7 \leq x$ \\
$7-5$, & $5 \leq x$ & $\frac{9-7}{9-7}$ & $\leq 9$ \\
0, & $x \geq 7$ & 1, & $x \geq 9$
\end{tabular}

Keanggotaan Netral :

$$
0, \quad x \leq 5
$$

$$
\begin{array}{rc}
\frac{x-5}{7-5}, & 5 \leq x \\
\frac{7-x}{9-7}, & \leq 7 \\
0, & 7 \leq x \\
& \leq 9 \\
& x 9
\end{array}
$$

b. Himpunan keanggotaan suhu

Dimana himpunan keanggotaan untuk suhu adalah dingin pada range antara dibawah 30 sampai dengan 32 derajat. Untuk keanggotaan hangat adalah range antara 32 sampai dengan 34 , dan keanggotaan panas adalah di atas 43 derajat celcius.

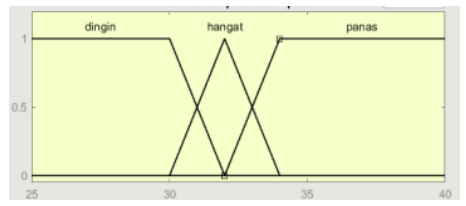

Gambar 11. Himpunan keanggotaan suhu

Jika dimasukkan kedalam Rumusan fungsi keanggotaan adalah sebagai berikut :

Keanggotaan dingin : Keanggotaan panas :

$$
\begin{array}{rrrr}
1, & x \leq 30 & 0, & x \leq 32 \\
\frac{32-x}{32-30}, & 30 \leq x & \frac{x-32}{34-32}, & 32 \leq x \\
\leq 32 & & & \leq 34 \\
0, & x \geq 32 & 1, & x \geq 34
\end{array}
$$

Keanggotaan hangat :

$$
\begin{array}{ll}
0, & x \\
\leq 30 & \\
\frac{x-32}{34-32}, & \\
\leq x \leq 32 & \\
\frac{34-x}{34-32}, & \\
\leq x \leq 34 & \\
0, & \\
0 \geq 34
\end{array}
$$

c. Himpunan keanggotaan kelembaban

Dimana himpunan keanggotaan untuk kelembaban adalah kering pada range antara dibawah 70 sampai dengan 80 . Untuk keanggotaan sedang adalah range antara 70 sampai dengan 90, dan keanggotaan lembab adalah di atas 90 .

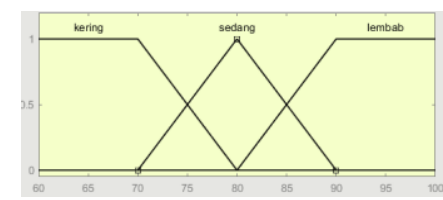

Gambar 12. Himpunan keanggotaan kelembaban

Jika dimasukkan kedalam Rumusan fungsi keanggotaan adalah sebagai berikut : 
Keanggotaan kering: Keanggotaan lembab:

$$
\begin{array}{rrrrr}
1, & x & \leq 70 & 0, & x \leq 80 \\
\frac{80-x}{80-70}, & 70 \leq x & \frac{x-80}{90-80}, & 80 & \leq x \\
0, & x & \geq 80 & & \leq 90 \\
& & 90 & & \geq
\end{array}
$$

Keanggotaan sedang:

$$
\begin{array}{rlrl}
0, & & x & \leq 70 \\
\frac{x-70}{80-70}, & & 70 & \leq x \\
& & \leq 80 \\
\frac{80-x}{90-80}, & & 80 & \leq x \\
& & \leq 90 \\
& \geq 90 & & x
\end{array}
$$

d. Himpunan keanggotaan nutrisi

Dimana himpunan keanggotaan untuk nutrisi adalah sangat kurang pada range antara dibawah 500 sampai dengan 600. Untuk keanggotaan kurang adalah range antara 600 sampai dengan 700, dan keanggotaan cukup adalah di atas 700 .

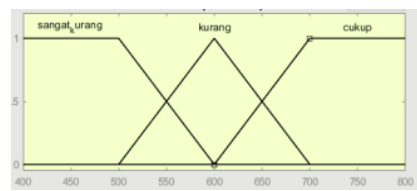

Gambar 13. Himpunan keanggotaan nutrisi

Jika dimasukkan kedalam Rumusan fungsi keanggotaan adalah sebagai berikut :

Keanggotaan sangat kurang:

$$
\begin{aligned}
& \text { 1, } x \leq 500 \\
& \frac{600-x}{600-500}, \quad 500 \leq x \leq 600 \\
& 0, \quad x \geq 32
\end{aligned}
$$

Keanggotaan kurang:

$$
\begin{array}{rlrl}
0, & x & \leq 500 \\
\frac{x-500}{600-500}, & & 500 & \leq x \leq 600 \\
\frac{700-x}{700-600}, & & 600 & \leq x \leq 700 \\
0, & x & \geq 700
\end{array}
$$

Keanggotaan sangat kurang:

$$
\begin{array}{rlrl}
1, & x & \leq 500 \\
\frac{600-x}{600-500}, & & 500 & \leq x \leq 600 \\
0, & x & \geq 32
\end{array}
$$

e. Himpunan keanggotaan suhu air

Dimana himpunan keanggotaan untuk suhu air adalah dingin pada range antara dibawah 28 sampai dengan 30 derajat. Untuk keanggotaan sedang adalah range antara 30 sampai dengan 32, dan keanggotaan panas adalah di atas 32 derajat.

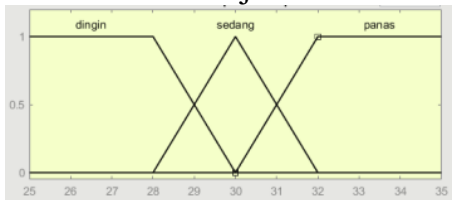

Gambar 13. Himpunan keanggotaan suhu air

Jika dimasukkan kedalam Rumusan fungsi keanggotaan adalah sebagai berikut :

Keanggotaan dingin: Keanggotaan panas:

$$
\begin{aligned}
& \begin{array}{llll}
1, & x \leq 28 & 0 & x \leq 30
\end{array} \\
& \frac{30-x}{30-28}, \quad 28 \leq x \quad \frac{x-30}{32-30}, \quad 30 \leq x
\end{aligned}
$$

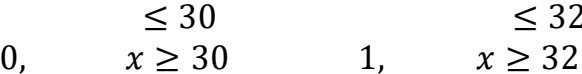

Keanggotaan sedang:

$$
\begin{array}{rc}
0, & x \leq 28 \\
\frac{x-28}{30-28}, & 28 \leq x \\
\leq 30 & \\
\frac{32-x}{32-30}, & 30 \leq x \\
\leq 32, & x \geq
\end{array}
$$$$
32
$$

\subsection{Rule Base Keanggotaan Fuzzy dan Deffuzifikasi}

Setelah mendapatkan nilai keanggotaan fuzzy kemudian nilai keanggotaan fuzzy akan masuk kedalam basis aturan.

a. Rule base suhu dan kelembaban

Rule untuk keanggotaan suhu memiliki 3 kondisi yaitu, dingin, hangat, dan panas. Untuk rule keanggotaan kelembaban memiliki 3 kondisi yaitu, lembab, sedang, dan kering. Untuk rule base suhu dan kelembaban yang akan digunakan pada proses logika fuzzy pada sistem dapat dilihat pada tabel 3 .

Tabel 3. Rule Base Suhu dan Kelembaban

\begin{tabular}{|c|c|c|c|}
\hline No. & Suhu & Kelembaban & Kondisi Pompa \\
\hline 1 & Dingin & Lembab & Mati \\
\hline 2 & Dingin & Sedang & Mati \\
\hline 3 & Dingin & Kering & Menyala \\
\hline 4 & Hangat & Lembab & Mati \\
\hline 5 & Hangat & Sedang & Mati \\
\hline 6 & Hangat & Kering & Menyala \\
\hline 7 & Panas & Lembab & Menyala \\
\hline 8 & Panas & Sedang & Menyala \\
\hline 9 & Panas & Kering & Menyala \\
\hline
\end{tabular}

b. Rule Base Suhu Air dan Nutrisi

Rule untuk keanggotaan suhu air memiliki 3 kondisi yaitu, dingin, sedang, dan panas. Untuk rule keanggotaan nutrisi memiliki 3 kondisi yaitu, sangat kurang, kurang, dan cukup. Untuk rule base suhu air dan nutrisi yang akan digunakan pada proses logika fuzzy pada sistem dapat dilihat pada tabel 4. 
Tabel 4. Rule Base Suhu Air dan Nutrisi

\begin{tabular}{|c|c|c|c|}
\hline No. & Suhu Air & Nutrisi & Kondisi Pompa \\
\hline 1 & Dingin & Sangat Kurang & Menyala Banyak \\
\hline 2 & Dingin & Kurang & Menyala Sedang \\
\hline 3 & Dingin & Cukup & Mati \\
\hline 4 & Sedang & Sangat Kurang & Menyala Banyak \\
\hline 5 & Sedang & Kurang & Menyala Sedang \\
\hline 6 & Sedang & Cukup & Mati \\
\hline 7 & Panas & Sangat Kurang & Menyala Banyak \\
\hline 8 & Panas & Kurang & Menyala Sedang \\
\hline 9 & Panas & Cukup & Mati \\
\hline
\end{tabular}

\section{c. Rule Base Suhu Air dan Ph}

Rule untuk keanggotaan suhu air memiliki 3 kondisi yaitu, dingin, hangat, dan panas. Untuk rule keanggotaan kelembaban memiliki 3 kondisi yaitu, asam, netral, dan basa. Untuk rule base suhu air dan ph yang akan digunakan pada proses logika fuzzy pada sistem dapat dilihat pada tabel 5.

Tabel 5. Rule Base Suhu Air dan Ph

\begin{tabular}{|c|c|c|c|}
\hline No. & Suhu Air & Ph & Kondisi Pompa \\
\hline 1 & Dingin & Asam & Ph Up menyala banyak \\
\hline 2 & Dingin & Asam & Ph Up menyala banyak \\
\hline 3 & Dingin & Asam & Ph Up menyala banyak \\
\hline 4 & Sedang & Netral & Mati \\
\hline 5 & Sedang & Netral & Mati \\
\hline 6 & Sedang & Netral & Mati \\
\hline 7 & Panas & Basa & Ph Down menyala banyak \\
\hline 8 & Panas & Basa & Ph Down menyala banyak \\
\hline 9 & Panas & Basa & Ph Down menyala banyak \\
\hline
\end{tabular}

d. Defuzzifikasi

Setelah rule base didapatkan maka proses selanjutnya untuk menentukan nilai tegas yang digunakan untuk menentukan lama pompa menyala. Pada sistem ini menggunakan deffuzifikasi dengan menggunakan weighted average.

$$
W A=\frac{a_{1} z_{1}+a_{2} z_{2}+a_{3} z_{3}+\cdots+a_{n} z_{n}}{a_{1}+a_{2}+a_{3}+\cdots+a_{n}}
$$

Ket : - WA = Nilai rata-rata (Weighted Average) - nilai aturan ke- $\mathrm{n}$

- nilai indeks nilai output ke- $\mathrm{n}$

\subsection{Pengujian nodeMCU ESP8266}

Pengujian pada mikrokontroler nodeMCU ESP8266 menggunakan pengujian pengiriman data dari sensor tampilan android. Hasilnya bisa dilihat pada tabel 6.

Tabel 6. Pengujian nodeMCU ESP8266

\begin{tabular}{|c|c|c|c|}
\hline \multirow[b]{2}{*}{ No } & \multicolumn{2}{|c|}{ Waktu } & \multirow[b]{2}{*}{$\begin{array}{l}\text { Delay } \\
\text { (Detik) }\end{array}$} \\
\hline & $\begin{array}{c}\text { Waktu } \\
\text { Pengiriman }\end{array}$ & $\begin{array}{c}\text { Waktu Tampil } \\
\text { di android }\end{array}$ & \\
\hline 1 & 13.45 .08 & 13.45 .09 & 1 \\
\hline 2 & 13.45 .31 & 13.45 .32 & 1 \\
\hline 3 & 13.45 .55 & 13.45 .56 & 1 \\
\hline 4 & 13.46 .18 & 13.46 .18 & 1 \\
\hline 5 & 13.46 .40 & 13.46 .41 & 1 \\
\hline
\end{tabular}

Dari tabel 3 dapat diamati bahwa delay pada pengiriman data sudah sesuai yaitu 1 detik. Pada serial monitor waktu pengiriman pada pukul 13.45.08 kemudian waktu tampilan di android pada pukul 13:45:09 dan seterusnya

\subsection{Pengujian Sensor TDS}

Dalam pengujian sensor TDS yang digunakan dalam sistem mikrokontroler dilakukan pengujian perbandingan alat yang sama dengan petani dalam mengukur kadar larutan nutrisi yang ada dalam air. Tabel 7 menampilkan hasil dari pengujian sensor TDS.

Tabel 7. Pengujian Sensor TDS

\begin{tabular}{|c|c|c|c|}
\hline No & TDS Meter & Sensor TDS & Error \\
\hline 1 & 630 & 679 & $7.8 \%$ \\
\hline 2 & 536 & 570 & $6.3 \%$ \\
\hline 3 & 442 & 450 & $1.8 \%$ \\
\hline 4 & 443 & 426 & $3,8 \%$ \\
\hline 5 & 61 & 91 & $49.1 \%$ \\
\hline 6 & 42 & 74 & $76.1 \%$ \\
\hline 7 & 210 & 228 & $8.5 \%$ \\
\hline 8 & 149 & 177 & $18.7 \%$ \\
\hline 9 & 300 & 305 & $1.6 \%$ \\
\hline 10 & 246 & 259 & $5.2 \%$ \\
\hline 11 & 35 & 67 & $47.7 \%$ \\
\hline 12 & 72 & 92 & $27.7 \%$ \\
\hline 13 & 89 & 112 & $25.8 \%$ \\
\hline 14 & 233 & 245 & $5.1 \%$ \\
\hline 15 & 213 & 227 & $6.5 \%$ \\
\hline 16 & 112 & 120 & $7.1 \%$ \\
\hline 17 & 139 & 154 & $10.7 \%$ \\
\hline 18 & 191 & 213 & $11.5 \%$ \\
\hline 19 & 186 & 201 & $8 \%$ \\
\hline 20 & 192 & 217 & $13 \%$ \\
\hline \multicolumn{3}{|c|}{ Rata-rata } & $17.1 \%$ \\
\hline
\end{tabular}

Setelah melakukan 20 kali pengujian perbandingan dengan menggunakan TDS Meter maka hasil yang didapatkan adalah sensor TDS mikrokontroler memiliki rata-rata tingkat error sebesar $17,1 \%$.

\subsection{Pengujian Sensor PH}

Dalam pengujian sensor ph yang digunakan dalam sistem mikrokontroler dilakukan pengujian dengan membandingkan sensor dengan alat yang sama dengan petani dalam mengukur kadar larutan ph yang ada dalam air. Tabel 8 menampilkan hasil dari pengujian sensor $\mathrm{ph}$.

Tabel 8. Pengujian Sensor PH

\begin{tabular}{|c|c|c|c|}
\hline No & PH Meter & Sensor PH & Error \\
\hline 1 & 7.7 & 4.32 & $43.8 \%$ \\
\hline 2 & 6.5 & 3.09 & $52.4 \%$ \\
\hline 3 & 7.0 & 5.85 & $16.4 \%$ \\
\hline 4 & 4.5 & 3.82 & $15.1 \%$ \\
\hline 5 & 5.2 & 3,90 & $25 \%$ \\
\hline 6 & 2.8 & 1.84 & $34.2 \%$ \\
\hline 7 & 5.6 & 4.17 & $25.5 \%$ \\
\hline 8 & 4.0 & 2.83 & $29.2 \%$ \\
\hline 9 & 6.1 & 3.95 & $35.2 \%$ \\
\hline 10 & 8.2 & 6.50 & $20.7 \%$ \\
\hline
\end{tabular}




\begin{tabular}{|c|c|c|c|}
\hline 11 & 7.5 & 6.01 & $19.8 \%$ \\
\hline 12 & 3.8 & 2.83 & $25.5 \%$ \\
\hline 13 & 9.3 & 12.31 & $32.2 \%$ \\
\hline 14 & 8.5 & 7.12 & $16.2 \%$ \\
\hline 15 & 2.0 & 1.09 & $45.5 \%$ \\
\hline 16 & 3.0 & 2.06 & $31.3 \%$ \\
\hline 17 & 8.1 & 9.87 & $21.8 \%$ \\
\hline 18 & 7.3 & 5.85 & $19.8 \%$ \\
\hline 19 & 2.5 & 1.45 & $42 \%$ \\
\hline 20 & 7.5 & 6.15 & $18 \%$ \\
\hline \multicolumn{4}{|c|}{ Rata-rata } \\
\hline
\end{tabular}

Setelah melakukan 20 kali pengujian perbandingan dengan menggunakan $\mathrm{pH}$ Meter maka hasil yang didapatkan adalah sensor $\mathrm{pH}$ mikrokontroler memiliki rata-rata tingkat error sebesar $28.58 \%$.

\subsection{Pengujian Sensor DHT22}

Dalam pengujian sensor DHT22 yang digunakan dalam sistem mikrokontroler dilakukan pengujian perbandingan data sensor dengan termometer. Tabel 9 menampilkan hasil dari pengujian sensor DHT22.

Tabel 9. Pengujian Sensor DHT22

\begin{tabular}{|c|c|c|c|c|c|c|}
\hline \multirow{2}{*}{$\begin{array}{c}\mathrm{N} \\
\mathrm{O}\end{array}$} & \multicolumn{2}{|c|}{$\begin{array}{l}\text { Termohigro } \\
\text { meter }\end{array}$} & \multicolumn{2}{|c|}{$\begin{array}{c}\text { Sensor } \\
\text { dht22 }\end{array}$} & \multirow{2}{*}{$\begin{array}{c}\text { erro } \\
\mathrm{r}\end{array}$} & \multirow{2}{*}{$\begin{array}{c}\text { No } \\
\text { Hum }\end{array}$} \\
\hline & $\begin{array}{c}\text { Suh } \\
\mathrm{u}\end{array}$ & $\begin{array}{c}\mathrm{Hu} \\
\mathrm{m}\end{array}$ & $\begin{array}{c}\text { Suh } \\
\mathrm{u}\end{array}$ & $\begin{array}{c}\mathrm{Hu} \\
\mathrm{m}\end{array}$ & & \\
\hline 11 & 30 & 59 & 31 & 11 & 30 & 59 \\
\hline 12 & 29 & 59 & 30 & 12 & 29 & 59 \\
\hline 13 & 29 & 60 & 30 & 13 & 29 & 60 \\
\hline 14 & 28 & 60 & 30 & 14 & 28 & 60 \\
\hline 15 & 28 & 60 & 30 & 15 & 28 & 60 \\
\hline 16 & 28 & 60 & 29 & 16 & 28 & 60 \\
\hline 17 & 28 & 60 & 28 & 17 & 28 & 60 \\
\hline 18 & 27 & 59 & 27 & 18 & 27 & 59 \\
\hline 19 & 27 & 59 & 27 & 19 & 27 & 59 \\
\hline 20 & 28 & 59 & 27 & 20 & 28 & 59 \\
\hline \multicolumn{5}{|c|}{ Rata-rata } & $2 \%$ & $17.6 \%$ \\
\hline
\end{tabular}

Setelah melakukan 20 kali pengujian perbandingan dengan menggunakan termohigrometer setiap 15 menit sekali, maka hasil yang didapatkan adalah sensor DHT22 mikrokontroler memiliki rata-rata tingkat error sebesar untuk suhu adalah $2 \%$ dan untuk kelembaban adalah $17.6 \%$.

\subsection{Pengujian Alat Pada Sistem Monitoring \\ Tanaman Hidroponik}

Pengujian semua sistem monitoring dilakukan dengan pengujian pada semua kinerja sistem yang ada, baik kinerja komponen alat yang telah dibuat.

Pengujian pada sistem otomasi yang ada pada sistem monitoring ini yang bisa dilihat pada tabel 10 , 11, dan 12 .

Tabel 10. Pengujian alat indikator suhu dan kelembaban

\begin{tabular}{|c|c|c|c|c|c|}
\hline \multirow{2}{*}{ No. } & \multicolumn{2}{|c|}{ Data } & \multicolumn{2}{|c|}{ Pompa } & \multirow{2}{*}{$\begin{array}{c}\text { Lama } \\
\text { Menyala }\end{array}$} \\
\hline & Suhu & Kelembaban & Nyala & Mati & \\
\hline 1. & 25.70 & 70.50 & $X$ & $\checkmark$ & 0 \\
\hline 2. & 25.40 & 70.40 & X & $\checkmark$ & 0 \\
\hline 3. & 31.40 & 92.50 & $\checkmark$ & $x$ & $253 \mathrm{~ms}$ \\
\hline 4. & 34.60 & 95.70 & $\checkmark$ & $x$ & $280 \mathrm{~ms}$ \\
\hline 5. & 35.60 & 95.70 & $\checkmark$ & 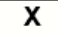 & $300 \mathrm{~ms}$ \\
\hline
\end{tabular}

Hasil pengujian alat untuk pompa pada indicator keanggotaan suhu dan kelembaban sudah berjalan sesuai yang diinginkan. Pompa akan mati ketika kondisi suhu dibawah 30 derajat dan kelembaban di atas 70. Pompa akan menyala ketika suhu berada di atas 30 derajat dan kelembaban dibawah 70 .

Tabel 11. Pengujian alat indikator suhu air dan nutrisi

\begin{tabular}{|c|c|c|c|c|c|}
\hline \multirow{2}{*}{ No. } & \multicolumn{2}{|c|}{ Data } & \multicolumn{2}{c|}{ Pompa } & Lama \\
\cline { 2 - 5 } & Suhu Air & Nutrisi & Nyala & Mati & Menyala \\
\hline 1. & 25.50 & 2.82 & $\checkmark$ & $\mathbf{X}$ & $300 \mathrm{~ms}$ \\
\hline 2. & 25.50 & 2.85 & $\checkmark$ & $\mathbf{X}$ & $300 \mathrm{~ms}$ \\
\hline 3. & 26.00 & 523 & $\checkmark$ & $\mathbf{X}$ & $253 \mathrm{~ms}$ \\
\hline 4. & 26.00 & 508 & $\checkmark$ & $\mathbf{X}$ & $280 \mathrm{~ms}$ \\
\hline 5. & 26.00 & 1755 & $\mathbf{X}$ & $\checkmark$ & 0 \\
\hline
\end{tabular}

Hasil pengujian alat untuk pompa pada indicator keanggotaan suhu air dan nutrisi sudah berjalan sesuai yang diinginkan. Pompa akan mati ketika kondisi nutrisi diatas 700 ppm. Pompa akan menyala ketika suhu berada dibawah 500 ppm.

Tabel 12. Pengujian alat indikator suhu air dan ph

\begin{tabular}{|c|c|c|c|c|c|c|c|}
\hline \multirow[b]{2}{*}{$\begin{array}{l}\mathrm{N} \\
\mathrm{o} .\end{array}$} & \multicolumn{2}{|c|}{ Data } & \multicolumn{2}{|c|}{$\begin{array}{c}\text { Pompa } \\
\text { Up }\end{array}$} & \multicolumn{2}{|c|}{$\begin{array}{l}\text { Pompa } \\
\text { Down }\end{array}$} & \multirow{2}{*}{$\begin{array}{c}\text { Lama } \\
\text { Meny } \\
\text { ala }\end{array}$} \\
\hline & $\begin{array}{c}\text { Suh } \\
\text { u } \\
\text { Air }\end{array}$ & $\mathrm{Ph}$ & $\begin{array}{c}\text { Nya } \\
\text { la }\end{array}$ & $\begin{array}{c}\mathrm{Ma} \\
\text { ti }\end{array}$ & $\begin{array}{c}\text { Nya } \\
\text { la }\end{array}$ & $\begin{array}{c}\mathrm{Ma} \\
\text { ti }\end{array}$ & \\
\hline 1. & $\begin{array}{c}25 . \\
50\end{array}$ & $\begin{array}{c}4.6 \\
8\end{array}$ & $\checkmark$ & $\mathbf{X}$ & $\mathbf{X}$ & $\checkmark$ & $\begin{array}{c}300 \\
\mathrm{~ms}\end{array}$ \\
\hline 2. & $\begin{array}{l}25 . \\
50\end{array}$ & $\begin{array}{c}4.4 \\
4\end{array}$ & $\checkmark$ & $\mathbf{X}$ & $\mathbf{X}$ & $\checkmark$ & $\begin{array}{c}300 \\
\mathrm{~ms}\end{array}$ \\
\hline 3. & $\begin{array}{l}26 . \\
00\end{array}$ & $\begin{array}{c}4.5 \\
0\end{array}$ & $\checkmark$ & $\mathbf{X}$ & $\mathbf{X}$ & $\checkmark$ & $\begin{array}{c}300 \\
\mathrm{~ms}\end{array}$ \\
\hline 4. & $\begin{array}{l}26 . \\
00\end{array}$ & $\begin{array}{c}4.3 \\
8\end{array}$ & $\checkmark$ & $\mathbf{X}$ & $\mathbf{X}$ & $\checkmark$ & $\begin{array}{c}300 \\
\mathrm{~ms}\end{array}$ \\
\hline 5. & $\begin{array}{c}26 . \\
00\end{array}$ & $\begin{array}{l}10 . \\
56 \\
\end{array}$ & $\mathbf{X}$ & $\sqrt{ }$ & $\sqrt{ }$ & $\mathbf{X}$ & $\begin{array}{c}300 \\
\mathrm{~ms}\end{array}$ \\
\hline 6. & $\begin{array}{l}26 . \\
00\end{array}$ & $\begin{array}{l}10 . \\
91\end{array}$ & $\mathbf{X}$ & $\sqrt{ }$ & $\sqrt{ }$ & $\mathbf{X}$ & $\begin{array}{c}300 \\
\mathrm{~ms}\end{array}$ \\
\hline 7. & $\begin{array}{l}26 . \\
00\end{array}$ & $\begin{array}{l}10 . \\
85\end{array}$ & $\mathbf{X}$ & $\checkmark$ & $\checkmark$ & $\mathbf{X}$ & $\begin{array}{c}300 \\
\mathrm{~ms}\end{array}$ \\
\hline 8. & $\begin{array}{l}26 . \\
00\end{array}$ & $\begin{array}{l}10 . \\
62\end{array}$ & $\mathbf{X}$ & $\checkmark$ & $\checkmark$ & $\mathbf{X}$ & $\begin{array}{c}300 \\
\mathrm{~ms}\end{array}$ \\
\hline
\end{tabular}

Hasil pengujian alat untuk pompa pada indikator keanggotaan suhu air dan ph sudah berjalan sesuai yang diinginkan. Pompa up akan mati ketika kondisi ph berada diatas 5 atau dalam kondisi netral dan asam. Sedangkan pompa up akan menyala ketika kondisi ph berada dibawah 5 atau dalam kondisi asam. Untuk pompa down akan mati ketika kondisi ph berada 
dibawah 9 atau dalam kondisi netral dan basa. Sedangkan akan menyala pada saat kondisi ph berada diatas 9 .

\subsection{Pengujian Sistem dengan Black Box}

Pengujian sistem merupakan proses menampilkan sistem dengan maksud untuk menemukan adanya kesalahan atau tidak pada fiturfitur aplikasi. Hasil pengujian sistem menggunakan metode black box ditunjukkan pada Tabel 13.

Tabel 13. Pengujian black box

\begin{tabular}{|l|l|l|l|l|}
\hline $\begin{array}{l}\text { N } \\
\text { o }\end{array}$ & $\begin{array}{l}\text { Pengujia } \\
\text { n }\end{array}$ & $\begin{array}{l}\text { Nama } \\
\text { Event }\end{array}$ & $\begin{array}{l}\text { Hasil } \\
\text { Yang } \\
\text { Diharapk } \\
\text { an }\end{array}$ & $\begin{array}{l}\text { Kesimpul } \\
\text { an }\end{array}$ \\
\hline 1 & $\begin{array}{l}\text { Menu } \\
\text { Data } \\
\text { Sensor }\end{array}$ & $\begin{array}{l}\text { Klik } \\
\text { Button } \\
\text { Data } \\
\text { Sensor }\end{array}$ & $\begin{array}{l}\text { Tampil } \\
\text { menu data } \\
\text { sensor }\end{array}$ & Berhasil \\
\hline 2 & $\begin{array}{l}\text { Menu } \\
\text { Hidropon } \\
\text { ik }\end{array}$ & $\begin{array}{l}\text { Klik } \\
\text { Button } \\
\text { Hidropon } \\
\text { ik }\end{array}$ & $\begin{array}{l}\text { Tampil } \\
\text { deskripsi } \\
\text { tentang } \\
\text { hidroponi } \\
\text { k }\end{array}$ & Berhasil \\
\hline 3 & $\begin{array}{l}\text { Menu } \\
\text { Temperat } \\
\text { ure }\end{array}$ & $\begin{array}{l}\text { Klik } \\
\text { Button } \\
\text { Temperat } \\
\text { ure }\end{array}$ & $\begin{array}{l}\text { Tampil } \\
\text { data } \\
\text { temperatu } \\
\text { re }\end{array}$ & Berhasil \\
\hline
\end{tabular}

\begin{tabular}{|c|l|l|l|l|}
\hline 4 & $\begin{array}{l}\text { Menu } \\
\text { Humidity }\end{array}$ & $\begin{array}{l}\text { Klik } \\
\text { Button } \\
\text { Humidity }\end{array}$ & $\begin{array}{l}\text { Tampil } \\
\text { data } \\
\text { humidity }\end{array}$ & Berhasil \\
\hline 5 & Menu Ph & $\begin{array}{l}\text { Klik } \\
\text { Button Ph }\end{array}$ & $\begin{array}{l}\text { Tampil } \\
\text { data ph }\end{array}$ & Berhasil \\
\hline 6 & $\begin{array}{l}\text { Menu } \\
\text { PPm }\end{array}$ & $\begin{array}{l}\text { Klik } \\
\text { Button } \\
\text { Ppm }\end{array}$ & $\begin{array}{l}\text { Tampil } \\
\text { data ppm }\end{array}$ & Berhasil \\
\hline
\end{tabular}

Hasil pengujian sistem monitoring dengan menggunakan pengujian black box menunjukkan bahwa, sistem dapat berjalan dengan baik. Pengujian yang dilakukan adalah dengan menjalankan aplikasi dengan menampilkan fitur menu data sensor, menu hidroponik, menu data temperature, data humidity, data ph, data ppm yang terdapat dalam menu data sensor yang berguna untuk menampilkan masingmasing data yang telah didapatkan dari sensor.

\section{KESIMPULAN DAN SARAN}

\subsection{Kesimpulan}

Berdasarkan beberapa pengujian yang telah dilakukan didapatkan kesimpulan :

1. Hasil pengujian alat monitoring dapat berjalan dengan baik, dan semua fitur program dapat berjalan sesuai dengan fungsinya.

2. Hasil pengujian pada sensor rata persentase error untuk sensor $\mathrm{Ph}=25.24 \%$. Sensor TDS $=17.1 \%$. Sensor DHT22 untuk suhu $=2 \%$, sedangkan kelembaban $=$ $17.6 \%$.

3. Hasil pengujian aplikasi berjalan dengan baik dengan semua fitur yang ada dan berjalan secara realtime.

\subsection{Saran}

Berdasarkan penelitian yang telah dilakukan, maka penulis dapat memberikan saran-saran untuk pengembangan selanjutnya antar lain :

1. Menambahkan grafik untuk monitoring.

2. Mengimplementasikan dengan menggunakan metode fuzzy lainnya, seperti metode fuzzy madm untuk melihat keakuratan metode.

3. Menggunakan sensor suhu, kelembaban, $\mathrm{pH}$, dan TDS dengan sensitifitas yang lebih baik.

\section{DAFTAR PUSTAKA}

[1] Purnomo, Rezak Andri. Implementasi Metode Fuzzy Sugeno Pada Embedded System Untuk Mendeteksi Kondisi Kebakaran Dalam Ruangan. Diss. Universitas Brawijaya, 2017.

[2] Saputra, Dede Irawan, Asep Najmurrokhman, and Zul Fakhri. "Skema Implementasi Fuzzy Inference System Tipe Sugeno Sebagai Algoritma Pengendali Pada Sistem Pengamatan Berbasis IoT." Prosiding Semnastek (2019).

[3] Logika, Menggunakan Konsep IoT Berbasis. "Implementasi Sistem Kontrol Irigasi Tetes Menggunakan Konsep IoT Berbasis Logika Fuzzy Takagi-Sugeno." (2019).

[4] robby Rizky, Robby, and Zaenal Hakim. "Implementasi Metode Fuzzy Sugeno Untuk Sistem Pengukuran Kualitas Udara Di Kota Pandeglang Berbasis Internet Of Things (IOT)." Syntax: Jurnal Informatika 9.1 (2020): 15-25. Nugroho, Hendro, 2017,

[5] Dinas pertanian, "bulelengkab.go.id", 13 Februari 2017. [Online]. Available: bulelengkab.go.id/detail/artikel/perbedaansistem-tanam-hidroponik-dan-akuaponik-40. Accessed 05 Desember 2020. 